\title{
Effect of feeding buttermilk coated diets on growth, carcass characteristics and production cost of crossbred chicken
}

\author{
GA Beyihayo ${ }^{1 *}$, PR Ntakyo ${ }^{2}$ and C Aturihaihi ${ }^{3}$
}

${ }^{1}$ Faculty of Agriculture and Environment, Gulu University P.O Box 166 Gulu, Uganda; ${ }^{2}$ Faculty of Agriculture and Environmental Sciences, Kabale University, P.O. Box 317, Kabale Uganda; ${ }^{3}$ Kyera Agricultural Training College P.O BOX 1577, Mbarara, Uganda

\begin{abstract}
Growth performance, carcass characteristics and production costs associated with feeding crossbred indigenous chicken on traditional buttermilk coated diets were evaluated. Three batches of day-old Indigenous $x$ Kuroiler crossbred chicks were raised on a commercial diet for one month. At one month, chicken in each of the three batches were weighed and randomly divided into 3 equal groups. Each group comprised of 20 birds. Chicken in each group were either fed coated (dry buttermilk coated maize-bran), combined (buttermilk coated maize bran + commercial diet) or a commercial (control) diet. Average final live weight and feed intake were similar across the three dietary treatments $(P>0.05)$. Feed to gain ratio significantly varied $(P<0.05)$ across dietary treatments with buttermilk coated diets having the highest feed to gain ratio (7.27) compared to combined (4.38) and commercial (3.88) diets. Coated and combined diets yielded similar dressing percentage of 60.2 and 62 compared to $65 \%$ obtained with commercial diets. Carcass and organ yield was similar $(P>0.05)$ across dietary treatments. On a 5 point hedonic scale, chicken meat produced using coated diets was more acceptable (2.0), compared to combined (2.1) and commercial (3.1) diets $(P<0.05)$. The highest gross margins accrued from feeding combined and commercial diets. Over-all, results provide evidence of the potential of the combined diet to attain similar growth performance, carcass yield and gross margins as the commercial diet at lower cost.
\end{abstract}

Keywords: buttermilk coated diets, production performance, profit margin, indigenous chicken

\section{Introduction}

Rural smallholder poultry farming is dominated by indigenous chicken eco-types, which account for berween 88 and 90percent of chicken population in Uganda (Olaboro, 1990; FAO, 2010; UBOS, 2018). In both urban and rural areas, consumers' preference for indigenous chicken is higher at 80 percent compared to 10 and 5 percent for spent hens and broilers respectively (Kyarisiima et al., 2011). The high preference for indigenous chicken is attributed to their meat being tastier, free from drugs and tough (Magala et al., 2012). In turn, this has led to doubling or tripling of the market price of indigenous chicken hence creating opportunities for rural farmers to increase their income (Kyarisiima et al., 2011). However, the potential of indigenous chicken has not been fully exploited to support the fight against malnourishment and poverty. The low productivity of chicken is attributed to multiple factors of which breed and feed related constraints dominate (Balikowa, et al., 2015).
The innate slow growth rate and feed related challenges among others account for the shortage in the supply of chicken due to delayed attainment of slaughter weight. Cross breeding with imported cocks has been shown to improve the rate of growth of indigenous chicken provided feeding is adequate (Kadigi et al. 2001; Sørensen and Ssewannyana, 2003, Semahoro et al., 2018). Adequate feeding under the intensive management system has also been shown to improve tenderness, juiciness, feed intake and live weight gain of indigenous chicken compared to a free-range management system (Magala et al., 2012; Kayitesi, 2015). The cost of conventional chicken feed is prohibitive as it is largely composed of fishmeal and soybean which are expensive and scarce animal and plant protein sources respectively. The high demand for fish and soybean by humans in addition to declining harvests increases the cost of feeds.

Traditional buttermilk is one alternative to the expensive conventional feeds. Traditional buttermilk is a non-conventional animal-protein source, containing protein of high biological 
value, full of essential amino acids, minerals, lactose and natural growth promoters (Bulut et al., 2012). In the South Western Rangelands of Uganda, over 200 liters of buttermilk are produced per cottage industry per week as the first by-product of local ghee processing (Unpublished data - Dairy Development Authority). Buttermilk costs less compared to fishmeal and soybean as a protein source but highly perishable due to its high water content, hence limiting its utilization as chicken feed. The common practice among households is to avail buttermilk as drinking water to the chicken.

Previously, Szczurek et al. (2013) reported increasing body weight gain and feed intake with more days of feeding dried buttermilk protein concentrated powder to broiler chicken. Kheiriet et al. (2015) revealed a linear increase in body weight gain and feed conversion efficiency due to addition of buttermilk powder in chicken feed. Omara, (2012) reported that apart from improving chicken performance and economic efficiency, buttermilk could also be used as a natural growth promoter. However, processing liquid buttermilk into a concentrated product with a long shelf life is costly (Formigoni et al., 2006) and not economically feasible in Uganda. Available literature is based on utilization of buttermilk processed into powder as opposed to liquid buttermilk. Shariatmadari and Forbes, (2005) suggested incorporating liquid milk byproducts in dry feed ingredients as a means of reducing their adverse effects.

Literature on appropriate low-cost buttermilk processing innovations is lacking. Affordable household processing technologies that prolong the storage life and increase the utilization of buttermilk as a protein source in chicken feed is one avenue of increasing chicken performance, household nutrition and profitability. Coating ingredients or mixed feeds with buttermilk prolongs the storage life of the later and enables its inclusion in chicken feed as an alternative protein source. Therefore, the objective of this study was to investigate the effect of dry buttermilk coated maize-bran based diets on growth performance, carcass characteristics and cost of meat production among crossbred chicken.

\section{Materials and Methods}

\section{Experimental birds and layout}

Fertile eggs were obtained by mating ten full sibling indigenous hens with a Kuroiler cock. Indigenous $x$ Kuroiler crossbred chicks were artificially hatched at intervals of three weeks, to produce three batches. Each batch of day-old chicks was artificially brooded separately for one month using a commercial diet containing 18percent crude protein with ad libitum access to water. Chicks were vaccinated against Marek's, Newcastle, Gumboro and infectious bronchitis. At the end of the brooding phase, each batch was trimmed to 60 chicks. Birds in each batch were weighed and randomly distributed into 3 groups of 20 birds (10males and 10females) at a stocking rate of $10 \mathrm{birds} / \mathrm{m}^{2}$. The groups were assigned to experimental diets in a completely randomized design (CRD) with three dietary treatments and replicates.

Table 1: The nutrient composition of experimental diets on dry matter basis

\begin{tabular}{|c|c|c|c|}
\hline Ingredients & Coated & Combined & $\begin{array}{c}\text { Commercial } \\
\text { (Control) }\end{array}$ \\
\hline $\begin{array}{l}\text { Coated Maize } \\
\text { bran }\end{array}$ & 88 & 43 & - \\
\hline Concentrate ${ }^{\#}$ & - & 10 & 20 \\
\hline Broken Maize & 11.5 & 47 & 78.5 \\
\hline $\begin{array}{l}\text { Di-calcium } \\
\text { Phosphate }\end{array}$ & & & 1.5 \\
\hline Brown Salt & 0.5 & & \\
\hline $\begin{array}{l}\text { Vitamin } \\
\text { Mineral } \\
\text { Premix }(\mathrm{kg})^{*}\end{array}$ & & & 0.5 \\
\hline Total(kg) & 100 & 100 & 100 \\
\hline \multicolumn{4}{|l|}{$\begin{array}{l}\text { Chemical } \\
\text { Analysis }\end{array}$} \\
\hline DM (\%) & 94.3 & 94.5 & 94.4 \\
\hline $\begin{array}{l}\text { Metabolizable } \\
\text { Energy (kcal } \\
\mathrm{kg}^{-1} \text { ) }\end{array}$ & 2822 & 2846 & 2805 \\
\hline $\begin{array}{l}\text { Protein- } \\
\text { CP(N×6.25) } \\
\%\end{array}$ & 150 & 150.4 & 150.8 \\
\hline $\begin{array}{l}\text { Total } \\
\text { Phosphorus } \\
\text { (\%) }\end{array}$ & 0.5913 & 0.6615 & 0.99175 \\
\hline Calcium (\%) & 3.1876 & 1.7749 & 0.7575 \\
\hline
\end{tabular}

*Vitamin mineral premix supplied per kilogram: Vitamin A, 50,000; Vitamin D3, 15,000; Vitamin E, $100 \mathrm{mg}$; Vitamin K3, 10; Iron(II) Sulphate, 225mg; Copper (E4), 75; Manganese, 300mg; Selenium, 2mg. " Percentage composition of concentrate: Crude Protein, 44; Crude Fat, 3.5; Crude Ash, 10.9: Crude Fiber, 5; Total Phosphorus, 1.45; Total Lysine, 3.07; Total Methionine, 1.44 and Total Methionine + Cystine, 2\%. 


\section{Experimental diets and feeding}

Each of the three groups in a batch was assigned to one of the three experimental diets which included; coated (dry buttermilk coated maizebran), combined (a combination of buttermilk coated maize bran and commercial diet) or a commercial (control) diet. Buttermilk coated maize bran was obtained through repeated mixing and sun drying of maize bran with buttermilk to a ratio of $1: 3(\mathrm{v} / \mathrm{v})$. The mixture was thereafter sundried to a dry matter content of 67 percent. The chemical composition of the diets is shown in Table 1 . All diets were isonitrogenous and isocaloric containing $150 \mathrm{~g} / \mathrm{kg}$ crude protein and a minimum of $2800 \mathrm{Kcal} / \mathrm{kg}$ respectively. All birds had ad libitum access to feeds and water.

\section{Growth performance and feed efficiency}

Feed intake and live weight gain were determined weekly. Feed intake was calculated as the difference between total feed offered and cumulative refusal over a period of one week. Birds were weighed on a weekly basis to determine live weight gain within the same period. Weighing of birds was carried out early in the morning before feeding. Data collected were used to calculate average daily feed intake (ADFI), Average daily weight gain (ADG) and feed conversion ratio (FCR) per diet for the growing period.

\section{Carcass characteristics}

At the onset of lay, 2 cockerels from each dietary treatment were fasted for 12 hours before being slaughtered. On slaughter, full carcass, carcass parts (breast, drumstick, thigh and drumstick + thigh), internal organs (gizzard, liver) were recorded. Dressing percentage was calculated as a proportion of hot carcass and live-weight.

\section{Sensory evaluation}

After weighing, breast meat was frozen for 24 hours. Upon thawing, skinless breast meat was sliced into $1 \mathrm{~m}^{2}$ cubes and steamed in aluminum foils for 30 minutes at $75^{\circ} \mathrm{C}$ as described by Magala et al. (2012). Sensory evaluation was carried out on flavor, tenderness, juiciness and overall acceptability using a 5point hedonic scale comprising of a10-memberpanel (Price and Schweight, 1971).

\section{Cost benefit analysis}

Effect of buttermilk coated diets on economic returns of crossbred indigenous chicken were evaluated. Cost of each diet was computed using the least cost formulation based on the unit cost of individual feed ingredients. Cost of other inputs including; veterinary services, management costs were recorded. Gross margin was calculated as difference in revenue accrued from the sale of chicken meat and cost of variable costs (feeding, veterinary and management costs).

\section{Statistical analysis}

Data collected were subjected to analysis of variance (ANOVA) using the general linear model package in $\mathrm{R}$ version 3.5.1 ( $\mathrm{R}$ Core Team, 2018). Treatment means were separated using the LSD at $5 \%$ level. The model used is shown below:

$\mathrm{Y}_{\mathrm{ij}}=\mu+\mathrm{T}_{\mathrm{ij}}+\mathrm{e}_{\mathrm{ij}}$

Where; $Y_{i j}=$ Response variable (e.g. ADFI, FCR);

$\mu=$ General mean; $T_{i j}=$ Effect of diet and $e_{i j}=$ Random error

\section{Results and Discussion}

\section{Chicken performance}

Growth performance and feed efficiency of crossbred indigenous chicken fed buttermilk coated based diets are summarized in Table 2. Chicken fed coated, combined and commercial diets had similar average final weights and daily feed intake-ADFI $(p>0.05)$.

Table 2: Growth performance, intake and feed efficiency of crossbred indigenous chicken fed buttermilk coated diets

\begin{tabular}{lrrrrr}
\hline & Coated & Combined & Commercial & \multicolumn{1}{c}{ SEM } & \multicolumn{1}{c}{ P -Value } \\
\hline Average Initial Weight $(\mathrm{Kg})$ & 1.004 & 1.081 & 1.054 & 0.264 & 0.958 \\
Average Final weight $(\mathrm{Kg})$ & 1.611 & 1.958 & 2.11 & 0.177 & 0.073 \\
Average Weight Gain $(\mathrm{Kg})$ & $0.608^{\mathrm{a}}$ & $1.130^{\mathrm{b}}$ & $1.331^{\mathrm{b}}$ & 0.356 & 0.0071 \\
ADFI (Kg) & 0.134 & 0.113 & 0.117 & 0.019 & 0.532 \\
FCR(feed/gain) & $7.27^{\mathrm{c}}$ & $4.38^{\mathrm{b}}$ & $3.88^{\mathrm{a}}$ & 0.471 & 0.00074 \\
\hline
\end{tabular}

$a, b, c$ Means within the same row with a different superscript are significantly different at $p<0.05 ;$ SEM, Standard error of mean. 
Chicken fed on combined and commercial diets had the highest and similar weight gain $(p<0.05)$ of 1.130 and $1.331 \mathrm{~kg}$ respectively compared to coated diets $(0.608 \mathrm{~kg})$. Save the case of coated diets, the results compare well with the results of the previous study by Magala et al. (2012) who reported an average weight gain of $0.940 \mathrm{~kg}$ for indigenous chicken raised on commercial diets. The variations in the observed results are partly attributed to the differences in genetic and nutritional composition of the commercial diets used in studies. Chicken raised using the commercial diet had the highest feed efficiency (FCR) while those fed on buttermilk coated diets had low efficiency $(P<0.05)$.

Similar studies have been conducted in other countries using whey instead of traditional buttermilk. In a related study, Kermanshahi et al. (2017) demonstrated that increasing the levels of acidified whey to 45percent does not affect feed intake, live weight gain and feed efficiency for broiler chicken reared for 42 days. Malik et al. (2015) also found no difference in feed intake, weight gain and feed conversion efficiency with diets containing up to 4percent dry whey. According to Ashour et al. (2015), live weight gain of broiler chickens was suppressed for the initial 3weeks due to inclusion of dried whey but no significant difference was observed afterwards up to 6 weeks. The same study reported significant and consistently low feed intake and conversion efficiency due to the inclusion of dry whey for the whole feeding period of 6 weeks. In contrast, Szczurek et al. (2013) reported improved feed conversion efficiency when levels of dry whey were increased to 3.2percent, however, body weight gain and feed intake was not affected during the same 42 day rearing period. The improved feed efficiency associated with higher inclusion levels of buttermilk could be explained by favorable gut $\mathrm{pH}$, healthy and increased protein digestibility.

\section{Dressing percentage}

The dressing percentage of indigenous chicken fed buttermilk coated based diets is presented in Figure 1. Dressing percentage was affected by diet. Chicken fed commercial diet had higher dressing percentage of 65 compared to 60.2 and 62 for coated and combined diets respectively. Under similar conditions, Magala et al. (2012) obtained a higher dressing percentage of 71 , compared to 65 for chicken fed a commercial diet in the current study. The dressing percentage of chicken fed buttermilk coated diet is in line with results reported by Szczurek et al. (2013). Ashour et al. (2015) reported increasing dressing percentage with higher levels of whey. Kayitesi (2015) found no difference in dressing percentage even when different breeds and management systems were considered.

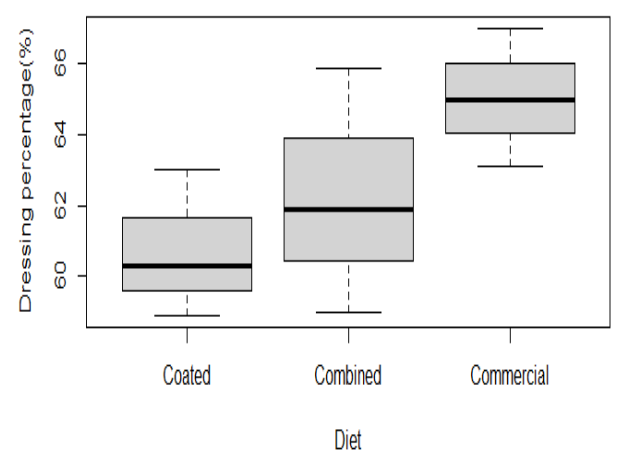

Figure 1: Dressing percentage of crossbred indigenous chicken fed buttermilk coated diets

Table 3: Carcass and organ yield of crossbred indigenous chicken fed buttermilk coated diets (kg)

\begin{tabular}{lcccccc}
\hline \multirow{2}{*}{ Feed Type } & \multicolumn{3}{c}{ Carcass Yield } & \multicolumn{2}{c}{ Organ Yield } \\
\cline { 2 - 7 } & Breast & Drumstick & Thigh & Drumstick + Thigh & Liver & Gizzard \\
\hline Coated & 0.149 & 0.177 & 0.197 & 0.371 & 0.041 & 0.063 \\
Combined & 0.220 & 0.233 & 0.247 & 0.465 & 0.045 & 0.076 \\
Commercial & 0.239 & 0.248 & 0.268 & 0.513 & 0.046 & 0.068 \\
SEM & 0.033 & 0.040 & 0.046 & 0.088 & 0.012 & 0.012 \\
P -Value & 0.073 & 0.234 & 0.350 & 0.333 & 0.917 & 0.553 \\
\hline
\end{tabular}

Means within the same column with a different superscript are significantly different at $P<0.05$. SEM, Standard error of mean. 
Table 4: Sensory evaluation of breast meat of chicken fed buttermilk coated diets

\begin{tabular}{lcccccc}
\hline \multirow{2}{*}{ Feed Type } & \multicolumn{5}{c}{ Sensation* } & $\begin{array}{c}\text { Over-All } \\
\text { Acceptability* }\end{array}$ \\
\cline { 2 - 5 } & Flavor & Tenderness & Juiciness & Taste & Solubility & \\
\hline Coated & 2.4 & 1.9 & 2.6 & 2.8 & $2.1^{\mathrm{c}}$ & $2.0^{\mathrm{a}}$ \\
Combined & 2.9 & 2.9 & 2.9 & 3.0 & $3.0^{\mathrm{b}}$ & $2.1^{\mathrm{b}}$ \\
Commercial & 2.6 & 2.6 & 3.0 & 3.0 & $3.5^{\mathrm{a}}$ & $3.1^{\mathrm{c}}$ \\
SEM & 0.56 & 0.48 & 0.42 & 0.61 & 0.42 & 0.43 \\
P -Value & 0.679 & 0.12 & 0.67 & 0.90 & 0.012 & 0.032 \\
\hline
\end{tabular}

$a, b, c$ Means within the same column with a different superscript are significantly different at $P<0.05 ;$ SEM, Standard error of mean; *Five-point scale scoring system: 1-Extremely very agreeable and 5-Extremely non agreeable.

\section{Carcass and organ yield}

Carcass and internal organ yield of crossbred chicken fed buttermilk coated diets are summarized in Table 3 . There is no significant difference $(p>0.05)$ in carcass (breast, drumstick, thigh and drumstick + thigh) and organ yield (liver and gizzard) across the dietary treatments. These results are in line with findings of Kermanshahi et al. (2017) who found no difference in liver, pancreas and heart weight as a result of including $45 \%$ dry whey in chicken feed. In this study, weight of all internal organs was similar across the different inclusion levels of dry buttermilk. Ashour et al. (2015) also reported similar results for thigh and breast yield across different inclusion levels of whey. In contrast, Szczurek et al. (2013) and Malik et al. (2015) reported an increase in breast and gizzard yield at higher inclusion levels of whey. However, liver yield was similar across the different inclusion levels of whey.

\section{Sensory evaluation}

Data collected from sensory evaluation of breast meat of chicken fed buttermilk coated based diets is summarized in Table 4. Flavor, tenderness, juiciness and taste of breast meat from chicken reared using the three dietary treatments do not show any significant difference $(P>0.05)$. Solubility of breast meat was higher in chicken fed buttermilk coated diet compared to commercial diets. On a five-point scale, breast meat from chicken fed coated diets was very soluble (2.1) on chewing. Breast meat from combined and commercial diets was soluble at 3.0 and 3.5 points respectively. Solubility increased with high levels of dry buttermilk in diets. High solubility values could be explained by the improved marbling capacity associated with increasing levels of buttermilk in feeds. In addition to being very soluble, breast meat produced by chicken fed buttermilk coated diets was more acceptable (2.0) compared to combined (2.1) and commercial diets (3.1). Over-all acceptability and palatability of meat is influenced by its tenderness, juiciness and solubility. The high acceptability values associated with buttermilk coated diets are due to its high tenderness, juicer and soluble meat. The high levels of tenderness, juiciness and solubility observed with coated diets are associated with high intramuscular fat. Fat causes meat to be tender through a number of mechanisms which include; replacing the tough muscle, lubricating the process of chewing and forming a soft tissue link between muscles (Lonergan et al., 2019).

\section{Production costs and economic benefits}

Cost, revenue and gross margin implications of feeding buttermilk coated diets to crossbred chicken are summarized in Table 5. Feeding commercial diets resulted into the highest variable costs followed by combined and lastly coated diets. Likewise, feeding commercial diets generated the highest revenue compared to coated and combined diets. Combined and commercial diets generated the highest and similar gross-margins compared to coated diets. This is due to the high live weight gain associated with combined and commercial diets, which fetched more income. However, coated diets resulted slightly into negative gross margins given its low live weight gain and subsequent reduction in revenue. Even when commercial diets generated more revenue, its gross margins were subsequently reduced by the high cost of feeding. Unlike in this study, Malik et al. (2015) reported increasing profitability with higher inclusion levels of buttermilk in feeds. 
Table 5: Costs, revenue and gross margin implications of feeding indigenous chicken buttermilk coated based diets (Ugandan shillings -Ug. Shs*)

\begin{tabular}{lccc}
\hline & Coated & Combined $^{\#}$ & Commercial \\
\hline Total feed cost (Ug. Shs) & 4,680 & 5,040 & 7,200 \\
Costs of other inputs & 1,500 & 1,500 & 1,500 \\
Live weight gain (kg) & 0.608 & 1.13 & 1.331 \\
Meat price per kg (Ug. Shs) & 10,000 & 10,000 & 10,000 \\
Variable costs (Ug. Shs) & 6,180 & 6,540 & 8,700 \\
Revenue & 6,080 & 11,300 & 13,310 \\
Gross Margin & -100 & 4,760 & 4,610 \\
\hline
\end{tabular}

Ug. Shs, Ugandan shillings; *US $1 \$=3600$ Ugandan shillings; ${ }^{*}$ Combined= Coated + Commercial diets

\section{Conclusion}

Commercial and buttermilk coated diets resulted in similar final live weight, feed intake and internal organ weight when fed to crossbred chicken. Although extra quantities of buttermilk coated diets are required to gain $1 \mathrm{~kg}$ of live weight gain, it costs less and ultimately reduces the cost of producing chicken meat. Supplementing buttermilk coated diets with commercial diets enhances their feed conversion efficiency. A reduction in the cost of feed will boost production and narrow the gap between demand and supply of chicken. The influence of traditional buttermilk coated diets on the on-set of lay, number of eggs per clutch and length of laying period need to be studied among indigenous chicken or their crosses.

\section{Acknowledgements}

Authors extend their gratitude to International Foundation for Science (IFS) for funding the study. Mrs. Eseza Rwentaro is much acknowledged for supplying the buttermilk and hosting the feeding trials.

\section{Conflict of interest}

There is no conflict of interest among the authors.

\section{References}

Ashour A, EE Elwy, E Mohamed and OA Osman (2015). Growth performance, carcass characteristics and blood serum biochemistry of broiler chickens fed different levels of dried Whey. International Journal of Current Research in Biosciences and Plant Biology 2(6): 1-8.
Balikowa D, MT Dhikusooka, GA Beyihayo and J Ruhinda (2015). Country Report on the Chicken Production Technologies in Uganda. Promotion of good management for increased productivity of market-oriented chicken producers. Dakar, Senegal. pp. 15-20.

Bulut S, A Birsen and A Nihat (2012). Functionality of whey protein. International Journal of Health and Nutrition 3: 1-7.

FAO (2009). A review of the current poultry disease control strategies in smallholder poultry production systems and local poultry populations in Uganda. AHBL - Promoting strategies for prevention and control of HPAI. Food and Agriculture Organization. Rome, Italy.

FAO (2010). Chicken genetic resources used in smallholder production systems and opportunities for their development, by $P$. Sørensen. FAO Smallholder Poultry Production Paper No. 5. Rome.

Formigoni A, A Piva, P Pezzi, G Castellani and G Biagi (2006). The influence of feeding fresh liquid whey on some blood metabolites, insulin, and cecal fermentations of growing pigs. Animal Feed Science and Technology 131(1-2): 53-66.

Kadigi HJS, CL Safalaoh and RKD Phoya (2001). Effect of crossbreeding the Malawi local chicken with the Black Australorp breed on selected egg production parameters. Indian Journal of Animal Science 71: 1071-1072.

Kayitesi A (2015). Management systems and location effects on growth and carcass traits of kuroiler and local chickens. Msc. Thesis Makerere University.

Kermanshahi H, RM Heravi, A Attar, AR Abbasi Pour, E Bayat, ZM Hossein, A Daneshm and SA Ibrahim (2017). Effects of acidified yeast and whey powder on performance, organ weights, intestinal microflora, and gut morphology of male broilers. Brazilian Journal. of Poultry Science 19(2): 309-315. 
Kheiriet F, F Rahimian and J Nasr (2015). Application of sumac and dried whey in female broiler feed. Arch. Animal Breeding 58: 205-210.

Kyarisiima CC, FA Nagujja , H Magala , H Kwizera, DR Kugonza and J Bonabana-Wabbi (2011) Perceived Tastes and Preferences of Chicken Meat in Uganda. LRRD, 23 (11) 2011. www.Irrd.org/Irrd23/11/kyar23242.htm

Lonergan SM and ND Marple (2019). Fat and fat cells in domestic animals. The Science of Animal Growth and meat technical book. https://scihub.bban.top/https://www.sciencedi rect.com/topics/veterinary-science-andveterinary-medicine/intramuscular-fat (accessed 13 July 2020)

Magala H, DR Kugonza, H Kwizera and CC Kyarisiima (2012). Influence of management system on growth and carcass characteristics of Ugandan local chickens. Journal of Animal Science Advances 2(6): 558-567.

Malik HEE, KM Elamin, SA Abdalla and BM Dousa (2015). Influence of supplemented whey on growth performance and internal organs percentages of broiler chickens. Online Journal of Animal Feed Resources 5(3): 68-73.

Olaboro G (1990). Smallholder Rural Poultry Production in Uganda. Country Report. pp.35.

Omara II (2012). Nutritive value of skimmed milk and whey added as natural probiotics in broiler diets. The Egyptian Society of Animal Production 49(2): 207-217.

Price JF and BS Schweigert (1971). The Science of Meat and Meat Products, San Francisco. USA.
R Core Team (2020). A language and environment for statistical computing. $R$ Foundation for Statistical Computing, Vienna, Austria. URL https://www.R-project.org/.

Semahoro F, D Kugonza, BM Babigumira, S Walusimbi, G Nadiope and MW Okot (2018). Growth performance of chicken genotypes based on indigenous populations of Eastern Uganda. Proceedings of the World Congress on Genetics Applied to Livestock Production, pages 557.

Shariatmadari F and JM Forbes (2005). Performance of broiler chickens given whey in the food and/or drinking water. British Poultry Science 46(4): 498-505.

Sørensen P and E Ssewannyana (2003). Progress in SAARI chicken breeding project - analyses of growth capacity. In Proceedings of the Livestock Systems Research Programme Annual Scientific Workshop, March 2003, Kampala, Uganda, pp. 172-178. 2003.

Szczurek W, B Szymczyk, A Arczewska-Włosek, D Józefiak and MN Alloui (2013). The effects of dietary whey protein concentrate level on performance, selected intestinal tract and blood parameters, and thiobarbituric acid reactive substances in the liver and breast meat of broiler chickens. Journal of Animal and Feed Science 22: 342-353.

Uganda Bureau of Statistics (2018). Statistical abstract. Report on Agricultural Module. Uganda Bureau of Statistics, Entebbe, Uganda. 